\title{
LEGAL REQUIREMENTS FOR PARALLEL IMPORT OF MEDICINAL PRODUCTS FOR HUMAN USE LICENSE ISSUANCE AND POTENTIAL BARRIERS FOR PARALLEL TRADE IN THE REPUBLIC OF LITHUANIA
}

\author{
Mindaugas Zalepūga \\ Mykolas Romeris University, Faculty of Law, \\ Department of Philosophy of Law and Legal History \\ Ateities 20, LT-08303, Vilnius, \\ Telephone: (+370) 52714637 \\ E-mail: mindaugas.zalepuga@gmail.com
}

Received on 26 September, 2013; accepted 29 October, 2013

doi:10.13165/SMS-13-5-4-15

\begin{abstract}
Annotation. Parallel import of medicinal products is being defined as an import into the Republic of Lithuania outside the distribution network of the authorised distributor of the product granted marketing authorisation in another EEA Member State, which is identical to the medicinal product already granted marketing authorisation in the Republic of Lithuania or sufficiently resembling it. The majority of parallel import of medicinal products related cases in the Court of Justice of the European Union (hereinafter-CJEU) are dealing with barriers for parallel trade that occur in license issuance procedure. Therefore, the main goal of this article is to identify and analyse regulatory peculiarities of parallel import of medicinal products licence (hereinafter - parallel import licence or licence) issuance procedure that may create barriers for the parallel trade of medicinal products in the Republic of Lithuania. In order to achieve this task, the article evaluates the necessity of parallel import licence, analyses separate elements of this procedure, identifies its regulatory peculiarities and discusses whether these regulatory peculiarities are acceptable for the EU law.
\end{abstract}

Socialinių mokslų studijos / Societal Studies

(C) Mykolo Romerio universitetas, 2013

(C) Mykolas Romeris University, 2013
ISSN 2029-2236 (print), ISSN 2029-2244 (online) http://www.mruni.eu/lt/mokslo_darbai/SMS/ http://www.mruni.eu/en/mokslo_darbai/SMS/ 
The article concludes that domestic law of the Republic of Lithuania creates challenges for a parallel trader, as the EU law and the CJEU jurisprudence were not taken into account during the implementation of sufficient similarity criteria. A lack of detailed secondary legislation together with administrative problems may reduce the accessibility of the procedure and challenge the implementation of the requirement of the CJEU that this procedure should last "a reasonable time".

Keywords: parallel import, licence, medicinal products, pharmaceutical law, EU law.

\section{Introduction}

According to Article 2 part 57 of the Law on Pharmacy of the Republic of Lithuania, parallel import of medicinal products means "import into the Republic of Lithuania outside the distribution network of the authorised distributor of the product granted marketing authorisation in another EEA Member State, which is identical to the medicinal product already granted marketing authorisation in the Republic of Lithuania or sufficiently

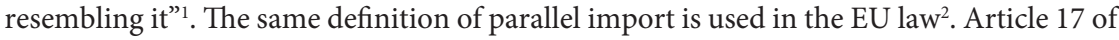
the above mentioned law that took force in 2006 defines the main conditions for parallel import and licence issuance procedure. However, parallel import of medicinal products is still at the rudimental stage in Lithuania. There are 229 medicinal products (this number includes variations) on the List of Parallel Import Medicinal Products ${ }^{3}$. The number of legal entities operating in the aerie of parallel import of medicinal products is also very limited.

On the other hand, it is problematic that parallel import of medicinal products is regulated by common norms of the primary EU law only, i.e. the parallel import is based on Article 34 (ex. 28) of the Treaty on the Functioning of the European Union ${ }^{4}$ (hereinafter - TFEU) and is subject to the derogations regarding the protection of human health and life and the protection of industrial and commercial property, as defined by Article 36 (ex. 30) of the TFEU. No special secondary legislation addresses the issue of parallel trade of medicinal products and the jurisprudence of the CJEU proofs that EU Member States differently interpret the primary law of the EU and so create obstacles for parallel trade of medicinal products. There are several cases at the Court of Justice of the

1 Law on Pharmacy of the Republic of Lithuania (translation) [interactive]. Vilnius, 2006 [accessed on 13-03-2013]. <http://www3.lrs.lt/pls/inter3/dokpaieska.showdoc_l?p_id=296798>.

2 Commission of the European Communities, Communication on Parallel Imports of Proprietary Medicinal Products for which Marketing Authorisations Have Already Been Granted. COM (2003) 839 final [interactive]; Brussels, 2003, 4 [accessed on 13-03-2013]. $<$ http://eur-lex.europa.eu/LexUriServ/LexUriServ.do?uri=COM:2003:0839:FIN:en:PDF>.

3 Valstybinè vaistų kontrolès tarnyba prie Lietuvos Respublikos Sveikatos Apsaugos Ministerijos. Lygiagrečiai platinamų Lietuvos Respublikoje vaistinių preparatų sąrašas [interactive]. Vilnius, 2013 [accessed on 11-09-2013]. <http://i2.alfi.lt/46/68/81.JPG>. 
European Union that are closely connected with domestic requirements of Member States for parallel import licence issuance procedure $\mathrm{p}^{5,6,7,8,9}$.

It may be hypothetically presumed that Lithuanian regulation may also create barriers for parallel trade of medicinal products in Lithuania that cannot be justified with the help of derogations defined in Article 36 of the TFEU. These barriers may make parallel import less attractive for legal entities and lead to a smaller number of parallel import medicinal products than in neighbouring EU countries with nearly the same pharmaceutical marked, e.g., there are 305 parallel import medicinal products (including variations) in the Register of Human Medicines in Latvia ${ }^{10}$. Respectively, questions may arise whether the current Lithuanian regulation is economically well grounded and whether it corresponds to the officially declared aims of national pharmaceutical policy that identifies priorities, such as reduction of prices of medicinal products and improvement of access to medicinal products, as well ${ }^{11}$. Meanwhile, parallel import, as such, is undoubtedly capable to achieve the above mentioned aims and current data show that the parallel trade industry has provided about 2.5 billion savings for Member States during the period of 2004-2009 and this trend is likely to be sustained in the future ${ }^{12,13,14}$. However, neither Lithuanian regulation of parallel trade of medicinal products, nor the economic consequences of it have been systematically analysed in scientific works in Lithuania ${ }^{15}$.

$5 \quad$ Case 104/75, de Peijper [1976] ECR 00613.

6 Case 15/74, Centrafarm v Sterling Drug [1974] ECR 01147.

7 Case C-112/02, Kohlpharma [2004] ECR I-03369.

8 Case C-113/01, Paranova Oy [2003] ECR I-04243.

9 Case C-212/03, Commission of the European Communities v French Republic [2005] ECR I-04213.

10 State Agency of Medicines of Latvia. Register of Human Medicines [interactive]. Riga, 2013 [accessed on 13-03-2013]. <http://www.vza.gov.lv/index.php?id=375\&top=334\&ON=\&IN=\& $\mathrm{RA}=\& \mathrm{PN}=\& \mathrm{RN}=\& \mathrm{M}=0 \& \mathrm{ATC}=\& \mathrm{P} \_\mathrm{U}=\& \mathrm{IN} \_\mathrm{C}=\& \mathrm{PI}=1>$.

11 Lietuvos Respublikos Seimo 2003 m. birželio 5 d. nutarimas Nr. IX-1604 „Dèl Lietuvos nacionalinès vaistų politikos nuostatų patvirtinimo“. Valstybės žinios. 2003, Nr.56-2488.

12 European Association of Euro-Pharmaceutical Companies. €2.5 Billion: Four Years of Parallel Distribution Savings for Europeans. Press Release. [interactive]. 23 January, 2012 [accessed on 15-12-2012].<http://www.eaepc.org/admin/files/130123_eaepc_press_release_final.pdf>.

13 Grossman, G. M.; Lai, E. C. L. Parallel Imports and Price Controls. RAND Journal of Economics. 2008, 39(2): 378-402.

14 Hostenkamp, G.; Kronborg, K.; Arendt, J. N. Parallel Imports of Hospital Pharmaceuticals: An Empirical Analysis of Price Effects from Parallel Imports and the Design of Procurement Procedures in the Danish Hospital Sector. Discussion Papers on Business and Economics. 2012, 16: $1-20$.

15 Some articles have analysed individual issues related to the parallel import of medicinal products and, according to the author, they do not represent a systematic review. Eg., Širinskiene, A; Zalepūga, M. Perpakavimo ịtakos lygiagrečiai importuojamų vaistinių preparatų kokybei vertinimas Europos Sąjungos teisingumo teismo jurisprudencijoje. Sveikatos mokslai. 2011, 1(73): 3854-3860. Širinskienè, A.; Zalepūga, M. Lygiagretaus patentinių vaistinių preparatų importo apribojimai Lietuvos Respublikos stojimo sutartyje. Visuomenés sveikata. 2011, 1(52): 42-49. Širinskienè, A.; Zalepūga, M. Lygiagrečiai importuojamų vaistinių preparatų kainodaros reguliavimo problemos Lietuvoje. Taikomieji tyrimai - visuomenes kaitai: moksliniu straipsniu rinkinys. 2011, 6: 128-135. 
Therefore, the main object of this article is regulation of parallel import of medicinal products license issuance procedure. The goal of the article is to identify and analyse regulatory peculiarities of parallel import of medicinal products licence issuance procedure that may create barriers for the parallel trade of medicinal products in the Republic of Lithuania. The following tasks are expected to be achieved:

1) evaluate the necessity of parallel import licence;

2) analyse the separate elements of the licence issuance procedure and identify its regulatory peculiarities;

3) evaluate whether regulatory peculiarities identified in task II are acceptable according to the EU law.

Systematic and comparative analyses together with the method of synthesis are going to be used in this article.

\section{Necessity of Parallel Import Licence Issuance Procedure}

A medicinal product may be put on the market of the EU Member State, when a marketing authorisation was granted at a national level in accordance with the provisions of the Directive 2001/83/EC ${ }^{16}$ or at the Community level in accordance with the provisions of Regulation $2309 / 93^{17}$. The main purpose of the above mentioned EU legal norms is the protection of public health. Thus, an obligation to obtain a marketing authorisation does not contradict the principle of free movement of goods.

However, parallel trade of medicinal products occurs, when a marketing authorisation has already been granted by several Member States and a medicinal product is lawfully on their market. In this case, competent authorities of Member States possess all the documents that were submitted by the marketing authorisation holder before the authorisation was granted; they have evaluated these documents and have made a decision that a medicinal product is safe for human use. Therefore, the question is whether an additional licence is necessary for the parallel import product and if this question is answered in negative, how the safety of a parallel import product (and protection of public health) must be guaranteed. These issues were addressed by the EUCJ in Centrafarm v Sterling Drug and de Peijper cases.

The court in Centrafarm v Sterling Drug had pointed out that there is a risk to import defective products and, therefore, "the protection of the public against risks arising from defective pharmaceutical products is a matter of legitimate concern, and article 30 [now article 36] of the treaty authorizes the Member States to derogate from the rules concerning the free movement of goods on grounds of the protection of health and life of humans and animals"18. The Court has also explained, that "the measures necessary to achieve this must be such as may properly be adopted in the field of health control

16 Directive 2001/83/EC of the European Parliament and of the Council of 6 November 2001 on the Community Code Relating to Medicinal Products for Human Use. [2001] OJ L 311.

17 Council Regulation (EEC) No 2309/93 of 22 July 1993 Laying Down Community Procedures for the Authorization and Supervision of Medicinal Products for Human and Veterinary Use and Establishing a European Agency for the Evaluation of Medicinal Products. [1993] OJ L214. Supra note 6, para. 27. 
$\langle\ldots\rangle^{19}$. However, the Court abstained from explanation what is being meant by "the measures necessary to achieve" and what are "properly adopted" measures. On the other hand, it may be observed, that the CJEU has agreed that Member States can adopt some national rules that are aimed at the protection of human health in case of parallel import of medicinal products.

The jurisprudence of the CJEU had a possibility to develop further in de Peijper. The facts of this case were significantly stimulating this development: a Dutch importer, Adriaan de Peijper, was prosecuted for importing a medicinal product from the UK without the approval of the Dutch competent authorities and without possessing either the product marketing authorization documents or the batch records ${ }^{20}$.

The Court recognised that as all relevant documents were already held by competent authorities, they should cooperate in making these documents available to each other ${ }^{21}$. If the parallelly traded and nationally authorised products were slightly different, it was up to the national competent authorities to investigate whether this difference was therapeutically significant. The only measures, which a national authority was justified in taking, were those intended to verify the identity of the product or sufficient similarity and the same therapeutical effect ${ }^{22}$. In conclusion, national competent authorities may not create barriers for parallel import of medicinal products by requesting parallel importers to satisfy the same requirements that are applicable to legal entities placing the product on the national market for the first time. A parallel importer is entitled to rely on medicinal product safety data collected at the expense of a marketing authorisation holder and the burden of proof rests on competent authorities. So, the CJEU has highlighted that the principle of relaxation of controls by national authorities in Member States is closely related to the principle of their cooperation ${ }^{23}$.

Following the de Peijper judgement, the European Commission announced a Communication on Parallel Imports of Proprietary Medicinal Products in $1982^{24}$, outlining basic principles of parallel import of medicinal products and the EU Member States were able to start developing simplified procedures for the parallel import license issuance ${ }^{25},{ }^{26},{ }^{27}$.

19 Supra note 6, para. 28.

20 Supra note 5, para. 2-8.

21 Ibid., para. 21-24.

22 Ibid., para. 33-36.

23 Kanavos, P.; Holmes, P. Pharmaceutical Parallel Trade in the UK. London: Civitas, 2005, p. 12.

24 Communication from the Commission of 6 May 1982 on Parallel Imports of Proprietary Medicinal Products. [1982] OJ C115.

25 Décret $\mathrm{n}^{\circ}$ 2004-83 relatif aux importations de médicaments à usage humain et modifiant le code de la santé publique (deuxième partie: partie réglementaire). Journal Officiel de la République Française. 2004, NOR: SANP0324239D.

26 Republic of Malta Parallel Importation of Medicinal Products Regulations. S.L.458.40.

27 Medicines Evaluation Board. Parallel import: authorisation and maintenance [interactive]. 2012, MEB-14-3.2 [accessed on 12-09-2012]. <http://www.cbg-meb.nl/NR/rdonlyres/3497782FF6A8-4437-846F-433F9C460ABD/0/120529parallelimportregistratie1432EN.pdf $>$. 
Later on, in case Commission v France, the Court has also acknowledged that the lack of national regulatory framework (absence of a simplified license issuance procedure for parallel import of medicinal products for plant protection) causes a failure of a Member State to fulfil its obligations under Article 28 (now Article 34 of the TFEU) ${ }^{28}$. It may be assumed from the above mentioned case, that a free movement of medicinal products creates a duty for a Member State to establish a certain regulatory framework. In such a case, there could be a legal problem with the evaluation of Lithuanian regulation just after the accession to the EU. Legal prerequisites for parallel trade of medicinal products for human use were established in 2006, when Law on Pharmacy took force, i.e., two years after Lithuania became the EU Member State. The issuance of licenses started in 2007, only when a specific simplified procedure was developed by the Ministry of Health ${ }^{29}$. Furthermore, no specific procedure for parallel import of medicinal products for animal use or plant protection has been developed up to now.

\section{Eligibility Criteria Applicable to Parallel Import Medicinal Products}

According to the Law on Pharmacy Art. 17 para. 3-4, medicinal products may be imported to the Republic of Lithuania, when they 1) are included into the List of Parallel Import Medicinal Products and 2) have a valid license for parallel import. Eligible for parallel import are only those medicinal products that are 1) identical to the medicinal product already registered in the Republic of Lithuania or 2) sufficiently similar to it. Medicinal products are considered sufficiently similar if they meet the following eligibility criteria:

1) the same active substance and the same salt of the active substance, the same ester, ether, isomer or mixtures of isomers, complexes or derivatives of an active substance of isomers;

2) the same strength;

3) the same pharmaceutical form and administration method;

4) the same clinical and pharmaceutical properties. Bioequivalence to a proprietary medicinal product with marketing authorisation in Lithuania is obligatory when a medicinal product to-be-imported is generic. In case a product with marketing authorisation in Lithuania and a product to-be-imported both are generics, they have to be bioequivalent to the same proprietary medicinal product ${ }^{30}$.

Neither the Law on Pharmacy, nor secondary legislation does not provide any clarity how the evaluation of sufficient similarity should be done and how the requirement for the products to be "the same" (in Lithuanian "tas pats") has to be interpreted in practice. Licensing procedure that was approved by the head of State Medicines Control Agency at the Ministry of Health of the Republic of Lithuania limits itself by stating that a senior

28 Case C-263/03, Commission v. France [2005] ECR I-05861, para. 19-20.

29 Sveikatos apsaugos ministro $2007 \mathrm{~m}$. balandžio 5 d. ịsakymas Nr. V-228 „Dèl vaistinių preparatų lygiagretaus importo taisyklių patvirtinimo“. Valstybės žinios. 2007, Nr. 39-1456. 
specialist evaluates whether the medicinal product is sufficiently similar to the product that has a marketing authorisation in Lithuania and makes a reference to two legal acts that have to be used for this evaluation: Law on Pharmacy and the Decree of the Minister of Health on the Rules of Parallel Import of Medicinal Products ${ }^{31 .}$ However, neither of these two legal acts provides any details on the processes of evaluation of sufficient similarity.

So, it might be assumed that there are no other rules of procedure and this means that an evaluation of similarity and an interpretation of criteria are left upon a person, who is applying the law. When technically important definition of "the same" is not fixed by the national law, a person applying the law is free to interpret "the same" (in Lithuanian "tas pats") as "identical in all aspects" 32 . Therefore, it could be acknowledged that the implementation of the rules of procedure by the SMCA did not solve the issue, which was raised by the Special Investigation Service in 2010, when it came to the conclusion that the regulation of license issuance procedure is not clear enough and is lacking transparency ${ }^{33}$.

On the other hand, criteria of sufficient similarity were addressed in numerous cases of the CJEU. Therefore, the article further will focus on the analysis of these cases, as it may deepen an understanding of problems with Lithuanian domestic regulation and may clarify whether an interpretation of "the same" as "identical in all aspects" is possible from the perspective of the EU law.

\subsection{CJEU Jurisprudence on Eligibility Criteria Applicable to Parallel Import Medicinal Products}

In de Peijper, the Court addressed a situation, when a qualitative and quantitative composition of a medicinal product imported by a parallel importer were different from those of a medicinal product that had marketing authorisation in a country of destination, when "the differences between the one and the other product are of such minor importance that it is likely that the manufacturer is applying or introducing .... these differences with the conscious and exclusive intention of using these differences .... in order to prevent or impede the possibility of the parallel importation of the proprietary medicinal product" ${ }^{\prime 4}$. De Peijper judgment concluded that the above mentioned variants of an already authorised medicinal product can be treated as similar to a product in a country of destination and may be imported in parallel as long as there are no differences of therapeutic significance between these products ${ }^{35}$. The meaning of "qualitative and quantitative differences in

31 Valstybinès vaistų kontrolès prie Lietuvos Respublikos Sveikatos apsaugos ministerijos viršininko 2010 m. spalio 11 d. ịsakymas Nr. P-587 „Dèl lygiagrečiai importuojamų vaistinių preparatų registravimo procedūros patvirtinimo“. Dokumento žymuo: 4/P-10:2010-10-1, para. 8-9.

32 Lietuvių kalbos žodynas [interactive]. Vilnius, 2011 [accessed on 05-11-2012]. <http://www. lkz.lt/>.

33 Lietuvos Respublikos Specialiųjų tyrimų tarnyba. Išvada dẻl korupcijos rizikos analizès Valstybineje vaistų kontrolès tarnyboje prie Sveikatos apsaugos ministerijos [interactive]. Vilnius, 2008 [accessed on 15-12-2012]. <http://www.stt.lt/documents/korupcijos_rizikos_analze/ VVKT_prie_SAM_KRA.pdf >,p. 22.

34 Supra note 5, para. 33.

35 Ibid., para. 34-36. 
composition" was left by the Court unexplained. The explanation of it may be found in other cases of the CJEU. The case Smith \& Nephew demands that the two products do not have to be identical in all respects, but they 1) should be manufactured according to the same formulation, 2) using the same active ingredient, and that they 3) have the same therapeutic effect ${ }^{36}$. This requirement was recited in the Communication of the Commission, $\operatorname{too}^{37}$. However, there is a slight difference between the Communication and in the CJEU ruling. It is a requirement of a common origin, that was not included into the Communication, but actually is a part of the judgement in case Smith \& Nephew and the judgement requires that manufacturers of both products in question should be part of the same group of undertakings or that they produce those medicinal products under agreements with the same licensor ${ }^{38}$.

The jurisprudence of the Court had a possibility to developed further in RhŏnePoulenc Rorer and May $\$$ Baker judgement. According to this judgement, a medicinal product may be regarded as sufficiently similar if a parallel imported product has the same active ingredients and therapeutic effect as a product with marketing authorisation, but does not use the same excipient and is manufactured by a different manufacturing process, provided that both products have the same therapeutic effect and the marketing authorisations referred to above are granted to different members of the same group of companies and manufacturers of both medicinal products belong to the same group. Furthermore, a parallel import licence remains valid even if a marketing authorisation was withdrawn in a Member State of destination. According to the CJEU, a Competent Authority in a Member State of destination, that is granting a license for parallel trade, should be in a position to verify that medicinal product to be imported complies with requirements relating to quality, efficacy and safety, and should be in a position to ensure normal pharmacovigilance ${ }^{39}$. Thus, the Court followed its practice in de Peijper case and repeated that qualitative differences (in this case, this is a difference in excipients) do not preclude products to be called "sufficiently similar" for the purpose of parallel trade and their composition is regarded in this case as being "the same". It may be also observed that the Court in Rhŏne-Poulenc Rorer and May $\$$ Baker judgement used common origin criteria as one of the elements that are necessary for the evaluation of sufficient similarity of proprietary medicinal products and clearly defined obligations of a Competent Authority that is assessing a request to grant a parallel import license.

In case Paranova $\mathrm{O} y$, the Court recognised that the difference in a pharmaceutical form (tablets versus capsules) and composition of active substance (omeprazole acid in capsules versus magnesium salt of omeprazole acid in tablets) do not make these products incomparable for the purpose of parallel import, provided that their therapeutic effect is the same (both products have the same dose of the active substance, which is absorbed

36 Case C-201/94, Smith and Nephew [1996] ECR 05819, para. 26.

37 Commission of the European Communities, supra note 2, p. 8.

38 Širinskiene, A.; Zalepūga, M. The Possibilities for the Implementation of Measures Facilitating and (or) Stimulating Parallel Import of Medicinal Products in Lithuania. Changes in Social and Business Environment. 2011, (4): 278. 
at the same rate and to the same extent $)^{40}$. Thus, it may be concluded that these two products - tablets and capsules - were regarded de facto as "sufficiently similar", even though the court did not use this wording in expresis verbis.

Several major changes in a licence issuance procedure occurred after the Kohlpharma case. Here, the court addressed the requirement of the common origin that was used by Member States for the comparison of "sufficient similarity". However, despite the existing practice, the court refused to acknowledge the requirement of the common origin as a necessary requirement for the evaluation of a sufficient similarity of a medicinal product to be imported and pointed out that "In the case where an application for a marketing authorisation for a medicinal product is submitted with reference to a medicinal product that has already been authorised;

- the medicinal product which is the subject of the application is imported from a Member State in which it has obtained a marketing authorisation;

- the assessment of safety and efficacy carried out for the medicinal product which is already authorised can be used in the application for a marketing authorisation for the second medicinal product without the risk to public health." ${ }^{41}$

According to the Court, Articles 34 and 36 of the TFEU preclude the application being rejected solely on the ground that the two medicinal products do not have a common origin $^{42}$. However, the Court suggested that a common origin can be "an important element" in determining comparability of two products, when a Competent Authority in a Member State has to evaluate whether the safety and efficacy assessment carried out for the medicinal product, which has already been authorised in a Member State, can be applied to the product that is going to be imported ${ }^{43}$. In such a way, the Kohlpharma judgement opened the gate for the parallel import of generic medicinal products. On the other hand, this judgment created uncertainty that is widely discussed among scientists ${ }^{44}$. There are even doubts if mutual recognition is needed for generic medicinal products, when a product approved in one Member State could be placed on the market of another one by obtaining a simplified license for parallel import that is based on the approval received by the marketing authorisation holder of the proprietary product in a Member State of destination ${ }^{45}$. On the other hand, the judgement did not tackle the issue of pharmacovigilance and, therefore, it is not clear how pharmacovigilance should be guaranteed when common origin of the product is missing.

40 Supra note 8, para. 14-15. It should be noted, that the difference in active substance was introduced by the manufacturer because of technical reasons only. It was easier to manufacture tablets than capsules since the salt dissolves more easily in water and is more stable.

41 Supra note 7, para. 21.

42 Ibid.

43 Ibid., para. 17

44 Kyle, M. K. Strategic Responses to Parallel Trade. NBER Working Paper Series. Cambridge: National Bureau of Economic Research, 2007, p. 10.

45 Faus, J. Similarity of Medicinal Products and Free Movement of Goods: Is Parallel Distribution the Beginning of the End for Mutual Recognition? Journal Of Generic Medicines. 2005, 3(1): $38-46$. 
A common origin was also addressed in case Commission of the European Communities $v$ French Republic. This case relates to plant protection products. The law of France required that both a product imported in parallel and a product with marketing authorization in France should have a common origin. The Commission considered that this requirement is a restriction on free movement of goods, which is contrary to Article 34 of the TFEU. The Commission in its decision explicitly relied on the Kohlpharma judgement. However, the CJEU pointed out the differences between the EU legislation applicable to medicinal products for human use and to plant protection products respectively and has made a conclusion that a requirement of common origin for plant protection products cannot be considered as contrary to Article 34 of the TFEU ${ }^{46}$. Thus, different levels of regulation of various types of medicinal products may result in different rules for the evaluation of their sufficient similarity. However, the questions raised by the Kohlpharma judgement and the emphasis on a common origin in the judgement Commission of the European Communities $v$ French Republic let us presume that there is a huge possibility of future litigations and that the Court will probably come back to the issue of a common origin when addressing sufficient similarity.

\subsection{Eligibility Criteria Applicable to Parallel Import Medicinal Products in Lithuanian National Law and Possible Barriers for Parallel Trade}

Turning back to the domestic law, it should be observed that it took nearly 5 years for Lithuania to start using the Kohlpharma judgement as a basis for legislation. Debates about the implementation of this judgement started in 2010 with the new draft of the Law on Pharmacy that took force in January $2012^{47}$. However, the problems with parallel import of generic medicinal products still remain. Systematic analysis of Articles 17 and 11 of the Law on Pharmacy shows that there could be some doubts about the legitimacy of parallel trade of generic medicinal products, as Article 17 paragraph 4 part 1 is left unchanged and the same salt of the active substance, the same ester, ether, isomer or mixtures of isomers, complexes or derivatives of an active substance of isomers are still required during evaluation of sufficient similarity. This may create barriers for parallel import of some generic products, because according to the Article 11 paragraph 8, a proprietary medicinal product and a bioequivalent generic product may have different salts, esters, ethers, etc.

The above analysis of the jurisprudence of the CJEU (especially the position of the Court in cases Paranova $\mathrm{Oy}$ and De Peijper) also supports the conclusion that barriers for parallel trade may occur with the national requirement for "the same strength" and "the

47 Lietuvos Respublikos farmacijos itstatymo 2, 4, 9, 12, 14, 17, 20, 23, 27, 33, 39, 55, 57, 62 ir 64 straipsnių pakeitimo ir istatymo priedo papildymo istatymo projektas [interactive]. Vilnius, 2010-07-01 [accessed on 02-03-2013]. <http://www3.lrs.lt/pls/inter3/dokpaieska.showdoc_ 1 ?p_id=377399>. 
same pharmaceutical form" ${ }^{\prime 4}$, when strength and form have no influence on a therapeutic effect and safety of a product. Furthermore, the interpretation of "sufficient similarity" in the domestic law may be one of the reasons leading to a low number of parallel import medicinal products in Lithuania, as it limits a number of products that are eligible for parallel trade. In practise, there have already been cases, when a parallel import licence was refused for products that are put on the market as "powder with solvent" in country of export and marketed as "powder" in Lithuania ${ }^{49}$. It should be observed that both products have had the same therapeutic effect.

On the other hand, while reflecting potential problems with the requirement of "the same strength" and "the same form" in the domestic law, it should be noted that marketing authorisation holders take different measures aimed at limiting parallel import, e.g., in 1989-1993, company Bayer introduced 24 different versions of the medicinal product called Adalat in the EU countries (all versions had different form and/or strength) with the aim to eliminate the possibility that those products will be evaluated as sufficiently similar for the purpose of parallel trade ${ }^{50}$. Therefore, the review of the domestic law and elimination of those norms that are inconsistent with the EU law and can aggravate the evaluation of sufficient similarity providing surplus requirements are inevitable measures that may facilitate parallel trade and help to increase the availability of low price medicinal products.

\section{3. "Reasonable Time" and "Accessibility" of Parallel Import License Procedure}

According to the CJEU, a national procedure that regulates the issuance of licenses for parallel import of medicinal products in a Member State of destination is supposed to be easily accessible (in French facilement accessible) and should "last a reasonable time" (in French dans un délai raisonnable) ${ }^{51}$. However, the Court has never explained in expresis verbis how accessibility and a reasonable time of the procedure are understood.

Reasonable time of the procedure was addressed by the European Commission in its Communication only. The European Commission pointed out that Directive 2001/83 defines a 90 days period, within which a Member State may decide on a recognition of a marketing authorisation issued by another Member State ${ }^{52}$. Therefore, the Commission suggests that the period of 45 days may be a reasonable time limit for a simplified procedure in case of parallel import. The same time limit of the procedure is defined by the national $\mathrm{law}^{53}$. This period begins when the Competent Authority (State Medicines Control Agency

50 Supra note 44, p. 12.

51 Supra note 28, para. 21; Supra note 9, para. 45-49.

52 Supra note 2, p. 7.

53 Supra note 1, Art. 17, para. 7.

Supra note 1, Art. 17, para. 3-4. mo nariams. Vilnius: Lexano, 2011.

Lygiagretaus importo vaistinių preparatų Lietuvoje apžvalga. Skirta Lietuvos Respublikos Sei- 
in Lithuania) accepts an application submitted according to the requirements established by the Minister of Health. The time spent by an applicant for provision of additional documents and necessary explanations required by the State Medicines Control Agency in not included in a 45 days period. No other time limit is defined in a secondary legislation, e.g., it is not clear in how many days the State Medicines Control Agency is obliged to review an application and make a decision that this application is submitted according to the national requirements; it is not clear when the State Medicines Control Agency has to contact a Competent Authority in a Member State of origin. The time needed for a communication with a Competent Authority in a Member State of origin may also exceed a period of 45 days, as the EU law does not define an exact number of days that is given to a Competent Authority in a Member State of origin for the preparation of documents that need to be send for a review in a Member State of destination. On the other hand, only two persons at the State Medicines Control Agency are responsible for the evaluation of medicinal products, which are to be imported, and the issuance of licenses. Furthermore, parallel import related duties are not their only duties at the State Medicines Control Agency $^{54}$. Thus, the capacities of the staff are rather limited. Therefore, the 45 days period is much longer in practice and in some instances it is significantly longer than the period needed for a marketing authorisation issuance procedure (e.g., a simplified procedure may take up to 580 days $)^{55}$. These facts suggest that domestic regulation of a license issuance procedure needs to be improved by adding specific deadlines, e.g., the ones for formal evaluation of documents submitted. On the other hand, administrative measures at the State Medicines Control Agency can be also reconsidered, as a limited number of staff employed and its constant overload with other duties may influence the functionality of an existing procedure.

\section{Conclusions}

1. A simplified parallel import license issuance procedure is a legitimate procedure based on Article 36 of the TFEU, as it ensures that parallel import products are not risky to the health and life of humans. Due to the need to ensure the same therapeutic effect, a number of parallel import medicinal products is limited to products that are regarded as identical or sufficiently similar if compared with the products marketed in a Member State of destination.

2. The EUCJ has developed a set of rules used for the comparison of sufficient similarity of products to be imported. Products having the same active substance, the same formulation and the same therapeutic effect are undoubtedly treated as sufficiently similar. However, it may be observed in the jurisprudence that wording "the same" does not mean "identical in all aspects" and there may be cases, when differences in an active substance (e.g., acid and salt of that acid) and in a pharmaceutical form (e.g., tablets

54 Darbuotojų atliekamos funkcijos ir specialieji reikalavimai jų pareigybei [interactive]. Vilnius, 2013 [accessed on 04-03-2013]. <http://www.vvkt.lt/lit/VVKT-darbuotoju-atliekamos-funkcijos-ir-specialieji-reikalavimai/800>. 
versus capsules) or in a quantity of an active substance may be regarded to be of minor importance and, therefore, products are treated as sufficiently similar for the purpose of parallel trade, provided that their therapeutic effect remains identical.

3. The EU law and the CJEU jurisprudence were not taken into consideration during the development of sufficient similarity criteria in Lithuania. This especially applies to the requirements of the same pharmaceutical form and the same strength. A lack of detailed secondary legislation together with administrative problems, such as a lack of personnel, may reduce the accessibility of the procedure and challenge the implementation of the requirement that the procedure should last "a reasonable time". Therefore, legislative measures should be taken in order to make a license issuance procedure more flexible and sufficient similarity criteria need to be adapted to the jurisprudence of the CJEU.

\section{References}

Case 104/75, de Peijper [1976] ECR 00613.

Case 15/74, Centrafarm v Sterling Drug [1974] ECR 01147.

Case C-112/02, Kohlpharma [2004] ECR I-03369.

Case C-113/01, Paranova Oy [2003] ECR I-04243.

Case C-201/06, Commission of the European Communities $v$ French Republic [2008] ECR I-00735.

Case C-201/94, Smith and Nephew [1996] ECR 05819.

Case C-212/03, Commission of the European Communities $v$ French Republic [2005] ECR I-04213.

Case C-263/03, Commission of the European Communities v France [2005] ECR I-05861.

Case C-94/98, Rhŏne-Poulenc Rorer and May \$ Baker [1999] ECR I-8789.

Commission of the European Communities, Communication on Parallel Imports of Proprietary Medicinal Products for which Marketing Authorisations Have Already Been Granted. COM (2003) 839 final [interactive]. Brussels, 2003 [accessed on 13-032013]. <http://eur-lex.europa.eu/LexUri Serv/LexUriServ.do?uri=COM:2003:0 839:FIN:en:PDF>.
Communication from the Commission of 6 May 1982 on Parallel Imports of Proprietary Medicinal Products. [1982] OJ C115.

Council Regulation (EEC) No 2309/93 of 22 July 1993 Laying Down Community Procedures for the Authorization and Supervision of Medicinal Products for Human and Veterinary Use and Establishing a European Agency for the Evaluation of Medicinal Products. [1993] OJ L214.

Darbuotojų atliekamos funkcijos ir specialieji reikalavimai jų pareigybei [interactive]. Vilnius, 2013 [accessed on 04-03-2013]. <http://www.vvkt.lt/lit/ VVKT-darbuotoju-atliekamos-funkcijos-ir-specialieji-reikalavimai/800>.

Décret $n^{\circ} 2004-83$ relatif aux importations de médicaments à usage humain et modifiant le code de la santé publique (deuxième partie: partie réglementaire). Journal Officiel de la République Française. 2004, NOR: SANP0324239D.

Directive 2001/83/EC of the European Parliament and of the Council of 6 November 2001 on the Community Code Relating to Medicinal Products for Human Use. [2001] OJ L311. 
European Association of Euro-Pharmaceutical Companies. €2.5 Billion: Four Years of Parallel Distribution Savings for Europeans. Press Release [interactive]. 23 January, 2012 [accessed on 15-12-2012]. <http:// www.eaepc.org/admin/files/130123 eaepc_press_release_final.pdf $>$.

Faus, J. Similarity of Medicinal Products and Free Movement of Goods: Is Parallel Distribution the Beginning of the End for Mutual Recognition? Journal of Generic Medicines. 2005, 3(1): 38-46.

Grossman, G. M.; Lai, E. C. L. Parallel imports and price controls. RAND Journal of Economics. 2008, 39(2): 378402.

Hostenkamp, G.; Kronborg, K.; Arendt, J. N. Parallel Imports of Hospital Pharmaceuticals: An Empirical Analysis of Price Effects from Parallel Imports and the Design of Procurement Procedures in the Danish Hospital Sector. Discussion Papers on Business and Economics. 2012, 16: 1-20.

Kanavos, P.; Holmes, P. Pharmaceutical Parallel Trade in the UK. London: Civitas, 2005.

Kyle, M. K. Strategic Responses to Parallel Trade. NBER Working Paper Series. Cambridge: National Bureau of Economic Research, 2007.

Law on Pharmacy of the Republic of Lithuania (translation) [interactive]. Vilnius, 2006 [accessed on 13-032013]. <http://www3.lrs.lt/pls/inter3/ dokpaieska.showdoc_l?p_id=296798>. Lietuvių kalbos žodynas [interactive]. Vilnius, 2011 [accessed on 05-112012]. <http://www.lkz.lt/>.

Lietuvos Respublikos farmacijos itstatymo $2,4,9,12,14,17,20,23,27,33,39,55$, 57,62 ir 64 straipsnių pakeitimo ir ịstatymo priedo papildymo istatymo projektas [interactive]. Vilnius, 2010-07-
01 [accessed on 02-03-2013]. <http:// www3.lrs.lt/pls/inter3/dokpaieska. showdoc_l?p_id=377399 $>$.

Lietuvos Respublikos Seimo 2003 m. birželio 5 d. nutarimas Nr. IX-1604 „Dèl Lietuvos nacionalinès vaistų politikos nuostatų patvirtinimo“. Valstybès žinios. 2003, Nr. 56-2488.

Lietuvos Respublikos Specialiųjų tyrimų tarnyba. Išvada dèl korupcijos rizikos analizès Valstybinejje vaistų kontrolès tarnyboje prie Sveikatos apsaugos ministerijos [interactive]. Vilnius, 2008 [accessed on 15-12-2012]. <http:// www.stt.lt/documents/korupcijos_rizikos_analze/VVKT_prie_SAM_KRA. pdf $>$.

Lygiagretaus importo vaistinių preparatų Lietuvoje apžvalga. Skirta Lietuvos Respublikos Seimo nariams. Vilnius: Lexano, 2011.

Medicines Evaluation Board. Parallel import: authorisation and maintenance [interactive]. 2012, MEB-14-3.2 [accessed on 12-09-2012]. <http://www. cbg-meb.nl/NR/rdonlyres/3497782FF6A8-4437-846F-433F9C460ABD/0/1 20529parallelimportregistratie1432EN. pdf $>$.

Republic of Malta Parallel Importation of Medicinal Products Regulations. S.L. 458.40.

Širinskienè, A.; Zalepūga, M. The Possibilities for the Implementation of Measures Facilitating and (or) Stimulating Parallel Import of Medicinal Products in Lithuania. Changes in Social and Business Environment. 2011 (4): 277283.

Širinskienè, A.; Zalepūga, M. Lygiagretaus patentinių vaistinių preparatų importo apribojimai Lietuvos Respublikos stojimo sutartyje. Visuomenès sveikata. 2011, 1(52): 42-49.

Širinskienè, A.; Zalepūga, M. Lygiagrečiai importuojamų vaistinių preparatų kai- 
nodaros reguliavimo problemos Lietuvoje. Taikomieji tyrimai - visuomenes kaitai: moksliniu straipsniu rinkinys. 2011, 6: 128-135.

Širinskienè, A; Zalepūga, M. Perpakavimo ịtakos lygiagrečiai importuojamų vaistinių preparatų kokybei vertinimas Europos Sąjungos teisingumo teismo jurisprudencijoje. Sveikatos mokslai. 2011, 1(73): 3854-3860.

State Agency of Medicines of Latvia. Register of Human Medicines [interactive]. Riga, 2013 [accessed on 13-032013]. <http://www.vza.gov.lv/index. php? id $=375 \&$ top $=334 \& \mathrm{ON}=\& \mathrm{IN}=\&$ $\mathrm{RA}=\& \mathrm{PN}=\& \mathrm{RN}=\& \mathrm{M}=0 \& \mathrm{ATC}=\& \mathrm{P}$ $\mathrm{U}=\& \mathrm{IN} \_\mathrm{C}=\& \mathrm{PI}=1>$.

Sveikatos apsaugos ministro $2007 \mathrm{~m}$. balandžio $5 \mathrm{~d}$. įsakymas Nr. V-228 „Dèl vaistinių preparatų lygiagretaus impor- to taisyklių patvirtinimo“. Valstybės žinios. 2007, Nr. 39-1456.

Treaty on the Functioning of the European Union (Consolidated version). [2012] OJ C326.

Valstybinè vaistų kontrolès tarnyba prie Lietuvos Respublikos Sveikatos Apsaugos Ministerijos. Lygiagrečiai platinamų Lietuvos Respublikoje vaistinių preparatų sąrašas [interactive]. Vilnius, 2013 [accessed on 11-09-2013]. $<$ http://i2.alfi.lt/46/68/81.JPG>.

Valstybinès vaistų kontrolès prie Lietuvos Respublikos Sveikatos apsaugos ministerijos viršininko $2010 \mathrm{~m}$. spalio $11 \mathrm{~d}$. įsakymas Nr. P-587 „Dèl lygiagrečiai importuojamų vaistinių preparatų registravimo procedūros patvirtinimo“. Dokumento žymuo: 4/P-10:2010-10-1.

\title{
REIKALAVIMAI ŽMOGUI SKIRTŲ VAISTINIŲ PREPARATŲ LYGIAGRETAUS IMPORTO LEIDIMŲ IŠDAVIMUI IR GALIMOS LYGIAGRETAUS IMPORTO İ LIETUVOS RESPUBLIKĄ KLIŪTYS
}

\author{
Mindaugas Zalepūga
}

Mykolo Romerio universitetas, Lietuva

Santrauka. Lygiagretus vaistiniu preparatu importas - kitoje EEE valstybejje registruoto vaistinio preparato, kuris yra tapatus Lietuvos Respublikoje jau registruotam vaistiniam preparatui ar pakankamai i ji panašus, įvežimas į Lietuvos Respublika nesinaudojant vaistinio preparato rinkodaros teisés turètojo platinimo tinklu - Lietuvoje yra i̇manomas nuo tada, kai Lietuva tapo ES nare. Tačiau iki šiol lygiagretus vaistiniu preparatu importas nera paplitęs. Antra vertus, straipsnyje atkreipiamas demesys $i$ tai, jog lygiagretus vaistiniu preparatu importas kyla iš laisvos prekybos principo. Šio principo taikyma farmacijos sektoriuje valstybès narès interpretuoja labai skirtingai. Kaip rodo Europos Sajungos Teisingumo Teismo praktika, toks skirtingas interpretavimas lemia ir prekybos laisvés suvaržymus, ypač tada, kai valstybèse narèse yra priimami sprendimai dèl lygiagretaus importo leidimu išdavimo. Dèl to straipsnio tyrimu objektu pasirinktas lygiagretaus vaistiniu preparatu importo leidimu išdavimo reguliavimas. Straipsnio tikslas - nustatyti ir nagrinèti lygiagretaus vaistiniu preparatų leidimu išdavimo reguliavimo ypatumus, jvertinant, ar jie nesukuria kliūčiu lygiagrečiam vaistiniu preparatu importui i Lietuvos Respubliką. 
Siekiant užsibrèžto tikslo straipsnyje pirmiausiai analizuojama, ar valstybèse narèse taikoma leidimų sistema yra būtina ir priimtina ES teisés atžvilgiu. Padarius išvadą, jog ši sistema nesukelia ES teisès pažeidimo, nagrinèjami atskiri leidimu sistemos elementai, daugiausiai demesio skiriant vaistiniu preparatu pakankamo panašumo vertinimo kriteriju analizei. Straipsnyje, remiantis Europos Sajungos Teisingumo Teismo jurisprudencija, atkreipiamas demesys $i$ tai, jog atskiru pakankamo panašumo vertinimo kriteriju (pvz., identiškos vaistinio preparato formos, identiško veikliosios medžiagos kiekio reikalavimas) taikymas gali pažeisti laisvo prekiu judejimo principa. Taip pat analizuojami ir leidimu išdavimo terminai bei administracinio pobūdžio apribojimai.

Daroma išvada, jog rengiant nacionalinès teisès aktus, reguliuojančius lygiagretaus vaistiniu preparatu importo leidimo išdavimo sistema, o ypač nustatant pakankamo panašumo kriterijus, nebuvo atsižvelgta į Europos Sajungos Teisingumo Teismo praktiką. Išsamaus poịstatyminio reguliavimo trūkumas drauge su administracinèmis problemomis - personalo stygiumi - gali apsunkinti lygiagretaus vaistiniu preparatų leidimu išdavimo prieinamuma ir kelti problemu siekiant, kad leidimai būtu išduodami „per protinga laiko tarpa", kaip kad reikalauja Europos Sajungos Teisingumo Teismas. Todèl įstatymu leidejas turètu imtis priemonių, kurios užtikrintų tinkama procedūros prieinamumą. Taip pat, atsižvelgiant ị Europos Sajungos Teisingumo Teismo praktiką, reikètu svarstyti apie Lietuvos Respublikos farmacijos ịstatymo pataisas, kuriomis būtu igyventinti minètojo teismo sprendimai, susiję su vaistiniu preparatų pakankamo panašumo vertinimu.

Reikšminiai žodžiai: lygiagretus importas, leidimas, vaistinis preparatas, farmacijos teise, ES teise.

Mindaugas Zalepūga, Mykolo Romerio universiteto Teisès fakulteto Teisès filosofijos ir istorijos katedros doktorantas. Mokslinių tuyomų kryptys: bioteisé, farmacijos teisè.

Mindaugas Zalepūga, Mykolas Romeris University, Faculty of Law, Department of Legal Philosophy and History, PhD student. Research interests: biolaw, pharmaceutical law. 